\title{
Kniha, která neměla být napsána (a pokud již byla, neměla být vydána).
}

\section{Rastislav Tóth: Politologický slovník}

\author{
Praha: Protál, 2015, 160 stran, ISBN 978-80-262-0807-5
}

\section{VLADIMÍR NAXERA ${ }^{1}$}

Slovníky jsou pro každý vědní obor jistě důležitými knižními útvary, které mají odborné (a často i laické) veřejnosti nejen vysvětlovat klíčové termíny daného oboru, ale zároveň svým čtenářưm říkají, které ze všech možných termínů v oboru jsou opravdu zásadní. Slovníky tedy pomáhají formovat diskurz v rámci daného oboru - ř́kají, co je důležité, a zároveň dané termíny a koncepty rámují určitým výkladem, který nebývá jediný existující. $V$ českém prostř̌edí existuje více či méně kvalitních slovníků $\mathrm{v}$ oborech politologie a mezinárodní vztahy několik a roku 2015 k nim přibyl další, tentokrát nepřiliš rozsáhlý Politologický slovník z nakladatelství Portál, jehož autorem je profesor Rastislav Tóth z Trnavské univerzity.

Již v úvodu je třeba říci, že posuzovaný text se potýká s celou řadou závažných problémů, které se pro přehlednost pokusím rozdělit do tři skupin (1) výběr představovaných pojmů, (2) obsah jednotlivých slovníkových hesel a (3) struktura a vyznění celé publikace. Prvním zmíněným kritickým bodem je zcela nejasný výběr pojmů, což souvisí s podobou úvodu celého textu, která zaslouží vlastní poznámku. Úvod je totiž ideálním místem, kde je dobré (nebo dokonce potřebné) osvětlit, dle jaké logiky byla vybírána hesla, která mají dle autora formovat poznání mimo jiné studentů společenských věd. Úvod dané knihy tuto funkci v žádném prrípadě neplní, spíše je přehlídkou řady klišé, floskulí a nepř́iliš přesvědčivých prohlášení. Za pozornost stojí již první odstavec úvodu: „Politologie je v Česku velmi mladou vědní disciplínou, podobně jako demokracie a občanská společnost. Všechny tři zmíněné oblasti však úzce souvisejí a všechny tři mají řadu společného: věkově jsou dospělými subjekty (je jim přes dvacet let), potřebují neustálou pozornost, mají stále své teenagerské mouchy. Veřejné mínění je nepřetržitě sleduje, kontroluje, kritizuje a žádá adekvátní rozvoj“ (s. 6). Opravdu

\footnotetext{
${ }^{1}$ Odborný asistent, Katedra politologie a mezinárodních vztahů FF ZČU v Plzni, Poděbradova 1, 30100 Plzeň, Ceská republika / Czech Republic. E-mail: vnaxera@kap.zcu.cz
} 
je rozvoj politologie kontrolován prostřednictvím veřejného mínění? $O$ něco níže se dočítáme, že „,[m]usíme se nejprve shodnout na tom, že politologie existuje a není formou preferování žádné ideologie či politického řádu. Jedná se o kombinaci popisu, analýzy a předvídání“ (s. 6). Jakkoli je diskutabilní první věta tohoto prohlášení, neobhajitelnost druhé je zcela zřejmá - opravdu má být politologie vědou věštění budoucnosti? Obecná část úvodu končí autorovou specifickou úvahou a výzvou: „Některé odborné termíny dnes plní úlohu „politických nadávek“, což je také projevem neuspořádanosti mysli. Pojd’me společně zvýšit míru efektivnosti uvažování, řízení a obecně vývoje společnosti“" (s. 7). Hodnocený slovník by měl být evidentně jedním z prostředků k naplnění autorova apelu.

Vrat'me se však k otázce výběru pojmů. Ve slovníku zcela zjevně chybí řada hesel, která $\mathrm{v}$ rámci politologie patři mezi nejčastěji užívané pojmy - nedozvídáme se napŕíklad, co to je stranický systém nebo liberalismus, ale dozvídáme se, co je Arlingtonský národní hřbitov, politický asketismus, válečný veterán nebo politická vize, což jsou, jak se domnívám, pro poznání základů politologie pojmy daleko méně relevantní, až zcela irelevantní. Stejně tak nalezneme hesla Kokkai (japonský parlament) a „Sněmovna reprezentantů (Japonsko)“ - včem je japonský zákonodárný sbor relevantnější než všechny ostatní parlamenty světa? Ze všech existujících mezinárodních organizací jsou jako samostatné heslo zařazeny pouze Evropská unie a Visegrádská čtyřka - opravdu jsou tyto ty nejdůležitější?

Kromě pojmů z oboru slovník obsahuje i řadu jmen, která lze rozdělit do tř́ skupin. Tou první jsou autoři, kteři přispěli $\mathrm{k}$ formování politického myšlení. Způsob jejich výběru je zcela záhadný. Proč je ve slovníku uveden J. de Mariana, ale není uveden T. Hobbes, J. Locke, J. J. Rousseau nebo Ch. L. de Montesquieu? Je snad možné se domnívat, že J. de Mariana přispěl politickému myšlení více, než tito autoři? Podíváme-li se na autory, kteři formovali obor politologie (resp. mezinárodní vztahy), i jejich výčet je zcela nahodilý - slovník obsahuje I. Wallersteina, G. Sartoriho, K. W. Deutsche, R. Dahla, Z. Baumana, D. Bella nebo R. Arona, což jsou vlastně téměř všechna obsažená jména. Tento výběr není rozhodně možné považovat za reprezentativní. Totožná (či ještě většî) nejasnost panuje ohledně výběru politických představitelů - jejich jména jsou vybírána zcela selektivně a bez jakéhokoli rozluštitelného klíče. Namísto představení politiků, o nichž běžně učíme studenty napříč všemi pracovišti (např. M. Thatcher, R. Reagan), jsou často představeni politici (chce se mi říci „druhořadého významu“) z přelomu minulého a předminulého století atd. (např. J. A. M. J. Juarés nebo R. Peel a dalšì).

Jak již bylo uvedeno výše, problematický není pouze záhadný způsob výběru hesel, ale i výklad velké řady z nich. Podívejme se nejprve na způsob představení dvou hesel, u kterých je možné se domnívat, že by pro politickou vědu měla být kruciální, totiž na politiku a moc, která s politikou neodmyslitelně souvisí. Pojem politika je ve slovníku představen více než stručně. Dočítáme se, že politika je 
„[č]innost politických subjektů. Podstatou by mělo být úsilí o obecné dobro pro všechny sociální, věkové, sexuální, rasové, etnické a jiné skupiny. Rozlišuje se podle charakteru státu a také zaměření (odvětvové politiky). Obsahuje operativní i koncepční stránku“ (s. 94). Poté následuje již pouze přesměrování na řadu dalších specifických pojmů jako politika menšinová, monetární, nepolitická, politika rozvoje měst atd. Samotný pojem politika je však vyložen extrémně jednostranným způsobem, bez zohlednění celého spektra př́stupů $\mathrm{k}$ tomu, co to politika je. Navíc pojem tak zásadní nemůže být nikdy vyložen takto stručným způsobem, zejména uvědomíme-li si, že část prostoru věnovanému heslu zabírají nic neř́ikající konstatování, že politika obsahuje „operativní i koncepční stránku“ k čemu čtenáři takové zjištění je? Aby toho nebylo málo, autor výklad hesla již v počátku zacyklí takovým způsobem, že se jeho pochopení stává nemožným pojem politika nemůže být vykládán jako činnost politických subjektů - co to je politický subjekt, když prozatím nevíme, co je to politika? Druhým pojmem je (politická) moc, jejíž výklad je již rozsáhlejší (zhruba jeden sloupek ve formátu A5, i když je třeba říci, že část textu se od tématu odklánî) a začíná slovy, že politická moc je „,[p]rávo politického subjektu přimět objekt politiky, aby uskutečnil určitý akt (změnil či zachoval své politické chovánî)“ (s. 81). Již v počátku je tedy moc ztotožňována s právem, což je zcela zavádějící - znamená to tedy, že mocí disponuje pouze ten, kdo na to má „právo“? Celý následující výklad hesla je zcela nepoznamenán bourlivou společensko-vědní debatou, která se $\mathrm{v}$ posledních desítkách let snažila odhalit podstatu a podobu politické moci.

Problematický není výklad pouze těchto základních konceptů, ale řady dalších hesel např́íc celým slovníkem. Podívejme se na některá z nich, která jsou vybraná spíše náhodně, ale jejichž prezentace dle mého soudu dobře ukazuje na zásadní obsahové problémy celého slovníku. Za první slovo můžeme vybrat např́klad libertarianismus. Tento pojem je definován jako „[e]xtrémní, bojovný liberalismus. Projevil se zejm. v době Velké fr. revoluce pronásledováním jejích nepřátel, politickými pouličními bitkami a popravami. Libertarianismus si definuje nepř́tele a bojuje proti němu všemi prostředky až po jeho zánik. Jde o ideologický fundamentalismus a nesnášenlivost. Okrajově se projevil i v období pádu komunistických systémů. Libertariáni považují stát za největší hrozbu svobody“ (s. 75-76). Netřeba př́liš rozvádět, že obstát by mohla snad jen poslední věta (a to pouze při určité interpretaci, a navíc nikoli v případě všech libertariánů). Jako další př́klad můžeme zvolit terorismus, kterým je rozuměno „[p]oužití násilí nebo jeho hrozby k dosahování politických cílů. Může mít individuální, skupinovou, fyzickou či ideologickou podobu. Ve středověku běžná součást vládnutí nebo změn vlády. V posledních desetiletích uplatňovaný v Evropě (Irsko, Španělsko, Německo, Itálie atd., na Blízkém východě i v jiných částech světa. Často je individuální forma kombinovaná s organizovanou formou“ (s. 136). Domnívám se, že rozporovat si zaslouží každá z vět této definice. Má-li být terorismus použitím násilí $\mathrm{k}$ prosazení politických cílů, jak by poté mohla být definována 
válka? Pokus o klasifikaci terorismu na individuální, skupinový, fyzický a ideologický zcela selhává, jelikož pouze první dva pŕípady jsou vymezeny společným kritériem. Terorismus nemůže mít zároveň ideologickou a skupinovou podstatu? Terorismus nebyl rozhodně něčím, co by vlády používaly pouze ve středověku (chceme-li vůbec pro stř́edověk operovat pojmem vláda), natož pak $\mathrm{v}$ př́padě, že si terorismus definujeme takovým způsobem jako autor slovníku. Z poslední věty se po selektivním výčtu zemí dozvídáme, že se terorismus „uplatňuje všude“.

Zmínit můžeme ještě další namátkou vybrané heslo - Iberoameričan - „,[...] Obyvatel Ameriky španěl. nebo port. etnického původu. [...]“ (s. 60). Hovořit $\mathrm{v}$ tomto př́padě o jedinci narozeném rodině, která žije v prostoru dejme tomu Argentiny po desítky generací, jako o někom se španělským etnickým původem, byt' by hovořil španělsky, je samozřejmě zcela zavádějící. Konečně můžeme uvést heslo média, které je bez jediného slova vysvětlení přesměrováno na heslo tisk, jako by bylo jeho synonymem.

Celá řada dalších hesel trpí zavádějícím, normativně jednostranným či selektivním výkladem, který často odporuje tomu, co je možná v rámci politické vědy považovat za dominantní pojetí. Pro zajímavost zmiňme alespoň letmo a nahodile ještě některá problematická tvrzení - politická kultura má být „proces a stav zušlecht’ování, rozvoj organizačních forem (správy) lidské komunity“ (s. 73) (autor tedy evidentně vytváŕí nesprávné rovnítko mezi pojmy politické kultura a „dobrá“ politická kultura), Karl Marx je bez jakéhokoli vysvětlení a kontextu označován za darwinistu (s. 78), všem ideologiím je implicitně přisuzován dialektický základ (s. 60), autor, namísto srozumitelného výkladu pojmu tř́́da, rozebírá velmi svérázným způsobem pojmy tř́́da politická a tř́da nepolitická (s. 139-140), včetně tak bizarních tvrzení, že třída nepolitická představuje v rozvinuté demokracii zhruba třetinu populace. Ve slovníku se vyskytuje pojem levičáctví (s. 75), což má být směr preferující zájmy nižších vrstev (je zajímavé, že pojem „pravičáctvii“ chybî), stejně tak je představen pojem levicová strana (s. 126), která má být opět orientovaná na uspokojování zájmů nižší tř́ídy - skutečnost, že autor zmiňuje tento pojem (a nevystačí si s představenými hesly strana socialistická a strana komunistická) a takto jej vykládá (společně s tím, že stejně jako „pravičáctvi“" chybí i heslo „pravicová strana“), ukazuje na to, že se sám nedokázal oprostit od ideologizace výkladu ve slovníku, což je něco, proti čemuž v úvodu sám brojí (viz výše).

K celkové podobě publikace je třeba prridat ještě několik obecnějších komentářu. Ten první souvisí se zcela absentujícím seznamem použitých zdrojů není tedy ani v náznaku patrné, na základě jaké literatury je konstruován výklad $\mathrm{v}$ daném slovníku. Toto považuji za zásadní prohřešek proti základům jakékoli práce mající byt' minimální odborné ambice. Absence seznamu zdrojů vyniká také v kontrastu ke skutečnosti, že publikace obsahuje (dokonce na prvním místě celé knihy) anglicko-jazyčné summary - je snad summary důležitější než seznam zdrojů 
(navíc u publikace, u které se dá očekávat minimální až nulový zahraniční ohlas)? Dále je třeba poznamenat, že nízká úroveň obsahového zpracování je zarážející vzhledem ke dvěma věcem. Tou první je to, že slovník měl (jak se dozvídáme z tiráže) projít recenzním ř́zením, druhou pak to, že publikaci vydalo poměrně renomované nakladatelství, z jehož produkce kromě řady zajímavých monografií před časem vzešlo dílo svým zaměřením obdobné, ale nesrovnatelně kvalitnější, totiž Encyklopedie mezinárodních vztahů (2009, Petr Kratochvíl a Petr Drulák eds.).

Jak je zjevné, dojem z hodnoceného slovníku není jakkoli pozitivní. Př́ležitost vydat po řadě let původní český politologický slovník byla tímto pokusem zmařena a je otázkou, zda by namísto takovýchto dalších podobných pokusů nebylo lepší přeložit některý z kvalitních slovníků zahraničních, který by mohl být doplněn o některá hesla zaměřující se na české politické reálie. Závěrem je třeba vyřknout naději, že se v úvodu formulovaný cíl slovníku, který má být př́nosem $\mathrm{k}$ uspořádanosti pojmů ve třech úhlech pohledu (odborném, mediálním a politickém), se naplní v co nejmenší možné míře, a slovník, především na studentech oboru, napáchá co nejmenší možné škody. 